\title{
Yield and Quality of Rainfed Cotton (Gossypium hirsutum L.) in Response to Nitrogen Rates under Different Plant Available Water Capacity Sites in Central Dry Zone of Myanmar
}

\author{
Thu Zar Win'1, Kyaw Ngwe1, Swe Swe Mar'1, Aye Aye Khaing² \\ ${ }^{1}$ Department of Soil and Water Science, Yezin Agricultural University, Naypyitaw, Myanmar \\ ${ }^{2}$ Department of Agronomy, Yezin Agricultural University, Naypyitaw, Myanmar \\ Email: thuzarwin.pb@gmail.com
}

How to cite this paper: Win, T.Z., Ngwe, K., Mar, S.S. and Khaing, A.A. (2021) Yield and Quality of Rainfed Cotton (Gossypium hirsutum L.) in Response to Nitrogen Rates under Different Plant Available Water Capacity Sites in Central Dry Zone of Myanmar. Open Access Library Journal, 8: e7891.

https://doi.org/10.4236/oalib.1107891

Received: August 25, 2021

Accepted: September 24, 2021

Published: September 27, 2021

Copyright $\odot 2021$ by author(s) and Open Access Library Inc.

This work is licensed under the Creative Commons Attribution International License (CC BY 4.0).

http://creativecommons.org/licenses/by/4.0/

\section{(c) (i) Open Access}

\begin{abstract}
The aim of this research was to explore the optimum nitrogen $(\mathrm{N})$ fertilizer rate for yield and quality of rainfed cotton under respective PAWC. A two-year field experiment was conducted in 2019 and 2020 during post-monsoon season at two sites, Pawaingyoe and Kokkokhahla, having different PAWC. Each year at both sites, six levels of $\mathrm{N}$ rate $(\mathrm{T} 1=0, \mathrm{~T} 2=60$, $\mathrm{T} 3=90, \mathrm{~T} 4=120, \mathrm{~T} 5=150$ and $\mathrm{T} 6=180 \mathrm{~kg} \mathrm{~N} \mathrm{ha}^{-1}$ ) were laid out in randomized complete block design with four replications and cotton variety Ngwechi-6 was tested. Results showed significant response of cotton to $\mathrm{N}$ fertilizer application in each year in both sites and it was consistently lower in 2020 compared to 2019. The DUL, CLL and PAWC of Pawaingyoe were higher than Kokkokhahla. Each year, all yield components and yield were superior in Pawaingyoe than Kokkokhahla. At Pawaingyoe in 2019, maximum values of yield components, seed cotton yield and NUE were achieved by T2. In 2020, all the yield components and yield were non-significant in all $\mathrm{N}$ applied treatments and the maximum NUE was found in T2. At Kokkokhahla in 2019, maximum values of yield components and seed cotton yield were obtained in T4, but, maximum NUE was observed in T3 and it gave $90.43 \%$ of maximum yield. In 2020, maximum values of yield components, seed cotton yield and NUE were achieved from T3. For fiber quality, T2 gave significantly higher fiber strength in Pawaingyoe, while T4 provided maximum fiber length and strength in Kokkokhahla during 2019. This study suggested that T2 $\left(60 \mathrm{~kg} \mathrm{~N} \mathrm{ha}^{-1}\right)$ would be the suitable rate for Pawaingyoe in both high and low rainfall condition (2019 and 2020). For Kokkokhahla, within the range between T3 and T4 (90 to $120 \mathrm{~kg} \mathrm{~N} \mathrm{ha}^{-1}$ ) would be appro-
\end{abstract}


priate in favorable rainfall condition as 2019 and T3 (90 kg N ha-1) might be

the most suitable rate in low rainfall such as 2020 .

\section{Subject Areas}

Plant Science

\section{Keywords}

Cotton, Nitrogen, Plant Available Water Capacity, Yield, Yield Components

\section{Introduction}

Cotton (Gossypium hirsutum L.) is one of the most important fiber crops playing a key role in economic and social affairs of the world [1]. It is likely to be thought that cotton cultivation and utilization have been started since in the early days of Myanmar history [2]. Cotton played an important role in the national economy of Myanmar [3] and it is the principal fiber crop of the country mainly sown in central dry zone (CDZ) during post-monsoon season as a rainfed crop. The CDZ area is characterized as semi-arid, moisture stressed and possessing low soil organic matter. Around the area, the varieties could not give substantial production without supplemental application of fertilizer to produce optimum yield and quality fiber. Dryland crop production is a function of both spatial and temporal availability of soil moisture within the field during the crop growth period. Low level of soil fertility and lack of soil moisture are the most important factors affecting the production of cotton both in quantity and quality in this area.

It is well known that under the same climatic conditions, soil characteristics are the key factors to sustain agricultural production. Soil can provide a buffer to store and supply water to the crop and therefore minimize the effects of severe drought. However, the soil's ability to support crop growth is largely dependent upon its water-holding and supply capacity [4]. Generally, water availability is the primary limiting factor for crop growth in the tropical semi-arid environment [5] such as the CDZ. Two moisture content levels, drained upper limit (DUL) or field capacity and crop lower limit (CLL) or permanent wilting point, are used to indicate the upper and lower limits of plant available water. Here, DUL is maximum amount of water, and the soil can hold against the gravity. CLL is the amount of water remaining after a particular crop, has extracted all the water available to it from the soil. PAWC is calculated as the difference between soil water content at DUL and soil water content at CLL. The maximum amount of available water that a soil can retain for the use of particular crop (i.e. PAWC) will vary with the soil's texture, structure, organic matter content and crop rooting depth [6].

Nitrogen $(\mathrm{N})$ is the plant's essential nutrient, the most important growth-limiting factor [7] among all the nutrients, and a pivotal factor for cotton production [8]. 
Nitrogen management is essential and critical in a dynamic crop like cotton. Hutmacher [9] stated that $\mathrm{N}$ is generally considered a yield limiting factor in both dryland and irrigated cotton production systems that focus on optimizing yield and avoiding excessive applications that reduce quality. Nitrogen fertilization in cotton requires a balanced approach as inadequate $\mathrm{N}$ limits yield and profits and excessive $\mathrm{N}$ is more likely and equally troublesome [10]. Efficient $\mathrm{N}$ management of cotton production is essential for both productivity and environmental perspectives in order to avoid a negative ecological impact and undesirable effects on the sustainability of agricultural production systems. Appropriate fertilizer use leads to increased crop yields and high crop recovery of applied nutrients. Furthermore, considering for saving farmer's cost is important because fertilizers are costly, and farmers with limited cash reserve have burden to invest on fertilizers and, thus, appropriate site-specific $\mathrm{N}$ management practices should be adopted. However, obtaining efficient fertilizer management based on average field conditions represents a significant challenge to many growers because $\mathrm{N}$ requirements often have extensive spatial variability [11]. Moreover, $\mathrm{N}$ management in cotton is particularly difficult due to problems with either excessive or inadequate rates or influence of abiotic stresses like drought [12]. Another problem concerning $\mathrm{N}$ is the most susceptible to losses than other macronutrients [13] and the $\mathrm{N}$ use efficiency is very low [14]. The key to $\mathrm{N}$ management is to provide adequate amounts rather than low or high amounts to the crop as it is needed by the crop [15].

The effect of $\mathrm{N}$ fertilization on rainfed cotton has not been extensively studied especially under different PAWC condition. Therefore, this study was conducted to observe the effects of $\mathrm{N}$ rates on yield and quality of rainfed cotton under different PAWC sites.

\section{Materials and Methods}

\subsection{Experimental Site}

This study was conducted at the two villages Pawaingyoe and Kokkokhahla of Pyawbwe Township in Mandalay Region, CDZ of Myanmar during post-monsoon season in 2019 and 2020. Pyawbwe is located at latitude $20.5977^{\circ} \mathrm{N}$, longitude $96.0494^{\circ} \mathrm{E}, 198$ meters above sea level. Pawaingyoe (N20.64682 $\left.^{\circ}, \mathrm{E} 96.22815^{\circ}\right)$ and Kokkokhahla $\left(\mathrm{N} 20.55128^{\circ}, \mathrm{E} 95.96853^{\circ}\right)$ are located in eastern and west-southern parts of Pyawbwe, respectively. Total $\mathrm{N}$ and available $\mathrm{N}$ were slightly higher in Pawaingyoe than Kokkokhahla for both years (Table 1). In Pawaingyoe, the values of ECEC, $\mathrm{OC}$ and $\mathrm{NO}_{3}^{-}-\mathrm{N}$ were higher, but saturated hydraulic conductivity values in all soil depths were lower than these values in Kokkokhahla (Table 2). Generally, Pawaingyoe was clay loam soil texture whereas Kokkokhahla was sandy loam soil texture.

\subsection{Experimental Design and Field Management}

In 2019 , following mung bean, cotton seeds were sown in the experimental plots 
Table 1. Some soil properties of Pawaingyoe and Kokkokhahla (from $0-20 \mathrm{~cm}$ depth).

\begin{tabular}{|c|c|c|c|c|c|}
\hline \multirow{3}{*}{ Parameters } & \multicolumn{4}{|c|}{ Analytical results } & \multirow{3}{*}{ Analytical Method } \\
\hline & \multicolumn{2}{|c|}{ Pawaingyoe } & \multicolumn{2}{|c|}{ Kokkokhahla } & \\
\hline & 2019 & 2020 & 2019 & 2020 & \\
\hline Total N (\%) & $0.05 \%$ (low) & $0.09 \%$ (low) & $0.01 \%$ (very low) & $0.04 \%$ (very low) & Kjaldehl distillation method \\
\hline $\begin{array}{c}\text { Available N } \\
\left(\mathrm{mg} \cdot \mathrm{kg}^{-1}\right)\end{array}$ & 47 (low) & 34 (low) & 29 (very low) & 26 (very low) & Alkaline permanganate method \\
\hline $\begin{array}{c}\text { Available P } \\
\left(\mathrm{mg} \cdot \mathrm{kg}^{-1}\right)\end{array}$ & 9.3 (low) & Not tested & 19.7 (medium) & Not tested & 9C-Olsen's P-Malachite green \\
\hline $\begin{array}{c}\text { Available K } \\
\left(\mathrm{mg} \cdot \mathrm{kg}^{-1}\right)\end{array}$ & 170 (medium) & Not tested & 300 (high) & Not tested & 15A1-1N Ammonium acetate extraction \\
\hline
\end{tabular}

Table 2. Physicochemical properties of different soil layers of Pawaingyoe and Kokkokhahla before planting.

\begin{tabular}{|c|c|c|c|c|c|c|c|c|c|c|c|}
\hline Sites & $\begin{array}{l}\text { Soil depth } \\
(\mathrm{cm})\end{array}$ & $\begin{array}{c}\text { pH } \\
(1: 5 \\
\text { soil:water })\end{array}$ & $\begin{array}{c}\text { EC } \\
(\mathrm{dS} / \mathrm{m}) \\
(1: 5 \\
\text { soil:water })\end{array}$ & $\begin{array}{c}\text { ECEC } \\
\mathrm{cmol}(+) \\
\mathrm{kg}^{-1}\end{array}$ & $\begin{array}{c}\text { OC } \\
\%\end{array}$ & $\begin{array}{l}\mathrm{NO}_{3}^{-}-\mathrm{N} \\
\mathrm{mg} \cdot \mathrm{kg}^{-1}\end{array}$ & $\begin{array}{c}\text { Hydraulic } \\
\text { Conductivity } \\
\mathrm{mm} \cdot \mathrm{hr}^{-1}\end{array}$ & $\begin{array}{c}\text { Sand } \\
\%\end{array}$ & $\begin{array}{l}\text { Silt } \\
\%\end{array}$ & $\begin{array}{c}\text { Clay } \\
\%\end{array}$ & Texture \\
\hline \multirow{7}{*}{ Pawaingyoe } & $0-10$ & 6.76 & 0.07 & 8.43 & 1.10 & 4.06 & 7.81 & 39.00 & 37.40 & 23.60 & Loam \\
\hline & $10-20$ & 6.44 & 0.06 & 7.67 & 1.04 & 4.19 & 7.64 & 42.00 & 36.70 & 21.30 & Loam \\
\hline & $20-30$ & 6.36 & 0.04 & 11.26 & 1.02 & 3.92 & 7.13 & 30.20 & 38.60 & 31.20 & Clay loam \\
\hline & $30-50$ & 6.72 & 0.05 & 10.35 & 1.82 & 3.51 & 6.45 & 33.70 & 34.50 & 31.80 & Clay loam \\
\hline & $50-70$ & 6.91 & 0.07 & 10.12 & 0.72 & 2.52 & 6.11 & 37.50 & 32.50 & 30.00 & Clay loam \\
\hline & $70-100$ & 7.22 & 0.04 & 13.30 & 0.57 & 2.29 & 5.94 & 26.20 & 38.40 & 35.40 & Clay loam \\
\hline & $100-150$ & 7.34 & 0.08 & 20.00 & 1.10 & 3.60 & 5.60 & 35.00 & 34.00 & 31.00 & Clay loam \\
\hline \multirow{7}{*}{ Kokkokhahla } & $0-10$ & 6.45 & 0.07 & 8.53 & 0.44 & 1.68 & 90.15 & 72.20 & 21.90 & 5.90 & Sandy loam \\
\hline & $10-20$ & 6.64 & 0.30 & 4.56 & 0.34 & 1.51 & 83.52 & 72.90 & 19.60 & 7.50 & Sandy loam \\
\hline & $20-30$ & 6.59 & 0.05 & 9.35 & 0.34 & 1.26 & 81.83 & 66.10 & 23.80 & 10.10 & Sandy loam \\
\hline & $30-50$ & 6.44 & 0.09 & 11.27 & 0.27 & 0.92 & 78.09 & 65.40 & 18.20 & 16.40 & Sandy loam \\
\hline & $50-70$ & 6.69 & 0.06 & 7.64 & 0.11 & 1.01 & 76.56 & 66.80 & 19.40 & 13.80 & Sandy loam \\
\hline & $70-100$ & 6.74 & 0.07 & 8.96 & 0.06 & 1.06 & 75.21 & 66.40 & 19.90 & 13.70 & Sandy loam \\
\hline & $100-150$ & 7.12 & 0.09 & 7.00 & 0.09 & 0.99 & 73.84 & 82.00 & 8.00 & 10.00 & Loamy sand \\
\hline
\end{tabular}

on 27 July in Pawaingyoe and on 4 August in Kokkokhahla. In 2020, the land was fallowed in summer and cotton seeds were sown in the same experimental plots on 27 July in Pawaingyoe and on 1 August in Kokkokhahla. The experimental plots were laid out in randomized complete block (RCB) design with four replications. Ngwechi- 6 cotton cultivar was used and the cotton plants were grown with the spacing $0.75 \times 0.75 \mathrm{~m}^{2}$. The total experimental area was 1147.44 $\mathrm{m}^{2}$ containing 24 plots. The area of each sub plot was $6.75 \times 6.75 \mathrm{~m}^{2}$ having 9 rows and 9 hills in each row. Six levels of $\mathrm{N}$ rate source as urea $(\mathrm{T} 1=0, \mathrm{~T} 2=60$, $\mathrm{T} 3=90, \mathrm{~T} 4=120, \mathrm{~T} 5=150$ and $\mathrm{T} 6=180 \mathrm{~kg} \mathrm{~N} \mathrm{ha}^{-1}$ ) were used as treatments and $\mathrm{N}$ was applied as split dose, i.e., $20 \%$ at sowing, $40 \%$ at squaring, $40 \%$ at flowering. For all treatments triple super phosphate $\left(60 \mathrm{~kg} \mathrm{P}_{2} \mathrm{O}_{5} \mathrm{ha}^{-1}\right)$, muriate of 
potash $\left(60 \mathrm{~kg} \mathrm{~K}_{2} \mathrm{O} \mathrm{ha}{ }^{-1}\right)$, zinc sulphate $\left(15 \mathrm{~kg} \mathrm{ha}^{-1}\right)$ and borax $\left(5 \mathrm{~kg} \mathrm{ha}^{-1}\right)$ were applied at basal. Cotton seeds were treated with dozar 20\% WP $0.25 \mathrm{~kg} \mathrm{ha}^{-1}$ to prevent from sucking pests at the seedling stage and field managements were implemented as the usual cultural practices. Thinning was done 18 days after emergence (DAE) and leaving two plants per hill. Pest control and other management practices were done as necessary. Management was taken across all the treatments in each experimental site. The same experimental design, used cultivar, plot size, treatments, all field management practices, data collections and data calculations were carried out for both sites in each year. A total of four pickings were done in 2019 for both sites. In 2020, four pickings were done in Pawaingyoe and only three times of pickings were done in Kokkokhahla.

\subsection{Measurements and Calculations}

\subsubsection{Sampling for Drained Upper Limit (DUL), Crop Lower Limit (CLL) and Bulk Density (BD)}

To measure DUL, the soil was wetted up, and then left to drain naturally without any moisture escaping by transpiration or evaporation. When the soil received sufficient rainfall, all vegetation of the selected area was cleaned and tarpaulins were placed over the site to seal and trap soil moisture. Weeds and other vegetation that surrounds the tarpaulin were removed to prevent them from using trapped water. When the soil was drained naturally and to get stable soil water content, DUL was measured for both sites and soil samples were collected to determine the gravimetric water content of the soil layers. In 2019, a soil pit was excavated to $1.5 \mathrm{~m}$ depth. The sample intervals were 0 - 10, 10 - 20, 20 - 30, 30 50, $50-70,70-100$ and $100-150 \mathrm{~cm}$. The samples were taken with three replicates from seven layers per site by using core ring which has $5 \mathrm{~cm}$ height and 2.5 $\mathrm{cm}$ radius. Since, the samples were taken by using a known volume core ring and thus $\mathrm{BD}$ of the soil can be determined. The fresh weights of samples (+jar) were measured in the field. Then, the samples were dried in an oven at $105^{\circ} \mathrm{C}$ until getting constant weight. In 2020, samples were collected by using an auger.

CLL was measured at crop maturity in each year. CLL samples were collected near the DUL site. For the surface layers, small pits were dug and the jars were filled with soil from the relevant layer. For deeper layers, an auger was used to obtain the sample making sure that the sample was from the correct interval. The samples were 3 replicates $\times 7$ layers per site and the depth intervals were the same as those used for DUL sampling. The fresh weight of samples (+jar) were measured in the field. Then the samples were dried at $105^{\circ} \mathrm{C}$ until constant weight and reweighed as the DUL. The following formulae were used in defining PAWC and its associated variables were measured according to [16].

$$
\begin{gathered}
\text { Gravimetric water }=\frac{(\text { wet weight of sample }- \text { dry weight of sample })}{\text { dry weight of sample }} \\
\text { Gravimetric water } \%=\frac{(\text { wet weight of sample }- \text { dry weight of sample })}{\text { dry weight of sample }} \times 100
\end{gathered}
$$




$$
\begin{gathered}
\text { Bulk density }\left(\mathrm{g} / \mathrm{cm}^{3}\right)=\operatorname{dry} \text { soil weight }(\mathrm{g}) / \text { total volume of } \operatorname{soil}\left(\mathrm{cm}^{3}\right) \\
\text { Core ring volume }\left(\mathrm{cm}^{3}\right)=\text { height } \times \operatorname{radius}^{2} \times \pi \\
\text { DUL }(\text { volumetric water } \%)=\text { Gravimetric water } \% \times \text { soil bulk density } \\
\text { CLL }(\text { volumetric water } \%)=\text { Gravimetric water } \% \times \text { soil bulk density } \\
\text { PAWC }(\mathrm{mm}) \text { for } 1 \text { depth interval }=[\text { DUL }- \text { CLL }] \times[\operatorname{depth} \text { interval }(\mathrm{cm}) / 10]
\end{gathered}
$$

PAWC for the full profile = sum of the PAWC for each depth interval (8) (where DUL and CLL are expressed as volumetric water \%)

\subsubsection{Crop Measurement}

Ten plants in the central three rows per plot were randomly tagged to determine yield and yield components. Yield components data such as number of bolls plant $^{-1}$, individual boll weight (grams of seed cotton boll ${ }^{-1}$ ), 1000 seeds weight and boll weight plant ${ }^{-1}$ were recorded at harvest time. Total seed cotton yield of each plot (including 10 plant subsamples) in the central three rows was weighed after sun dried and then this yield was calculated into yield per hectare. The cotton fiber quality such as fiber length, fiber strength, fiber fineness, maturity ratio and ginning out turn were measured at cotton fiber and yarn testing laboratory, Meiktila Township.

\subsubsection{Agronomic Nitrogen Use Efficiency (NUE)}

The agronomic NUE refers to an increase in seed cotton yield $\left(\mathrm{kg} \mathrm{ha}^{-1}\right)$ per unit of $\mathrm{N}$ applied [17]. The agronomic NUE was calculated based on the data collected for yield and applied $\mathrm{N}$ rate in both sites using the following formula.

$$
\text { Agronomic NUE }=\frac{\text { Yield }_{\mathrm{f}}-\text { Yield }_{0}}{\mathrm{~N} \text { apply }}
$$

where, Yield $_{\mathrm{f}}=$ seed cotton yield in a treatment with $\mathrm{N}$ application $\left(\mathrm{kg} \mathrm{ha}^{-1}\right)$, Yield $_{0}=$ seed cotton yield in a treatment without $\mathrm{N}$ application $\left(\mathrm{kg} \mathrm{ha}^{-1}\right), \mathrm{N}=$ the amount of fertilizer $\mathrm{N}$ applied $\left(\mathrm{kg} \mathrm{ha}^{-1}\right)$.

\subsection{Statistics}

The data obtained from this test were statistically analyzed with Statistix 8 software and the treatment means were done using Least Significant Difference (LSD) test at $5 \%$ level of significance.

\section{Results and Discussion}

\subsection{Weather Condition}

During the cotton growing season, Pawaingyoe received a total of $387 \mathrm{~mm}$ rain-fall in 2019 and $319 \mathrm{~mm}$ in 2020, while Kokkokhahla received a total of 515 $\mathrm{mm}$ in 2019 and $298 \mathrm{~mm}$ in 2020. The rainfall in 2019 at both sites was higher than 10-year average and the rainfall in 2020 at both sites was lower than 10-year average and 2019. The minimum and maximum temperatures ranges during 
2019 and 10-year average were similar in both sites. In 2020 at both sites, the minimum and maximum temperatures values were slightly higher than that of 10-year average and 2019 (Figure 1).

\subsection{DUL, CLL, PAWC and BD}

Each year, Pawaingyoe (clay loam) had higher amount of DUL, CLL and PAWC values than Kokkokhahla (sandy loam) in all soil depth (Figure 2). In 2019, total PAWC (up to depth of $150 \mathrm{~cm}$ ) of these soils were $250.78 \mathrm{~mm}$ in Pawaingyoe

\section{Pawaingyoe}

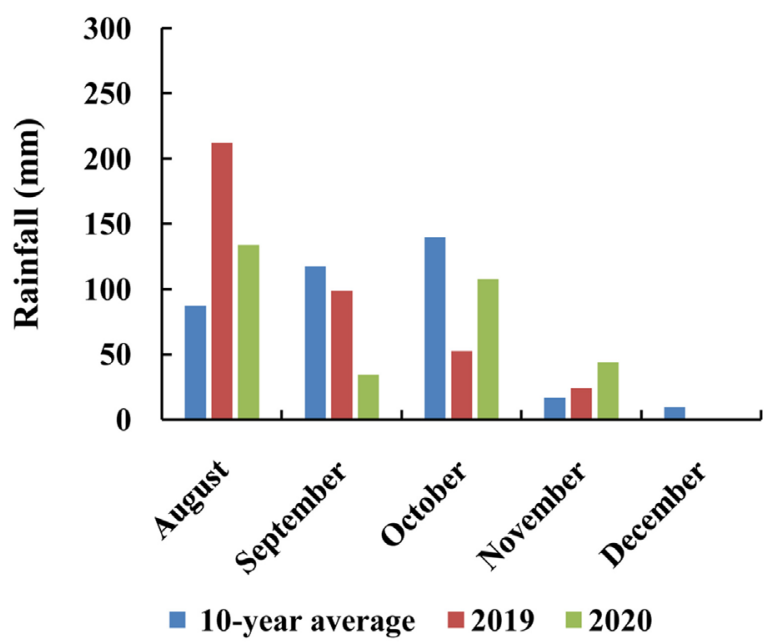

(a)

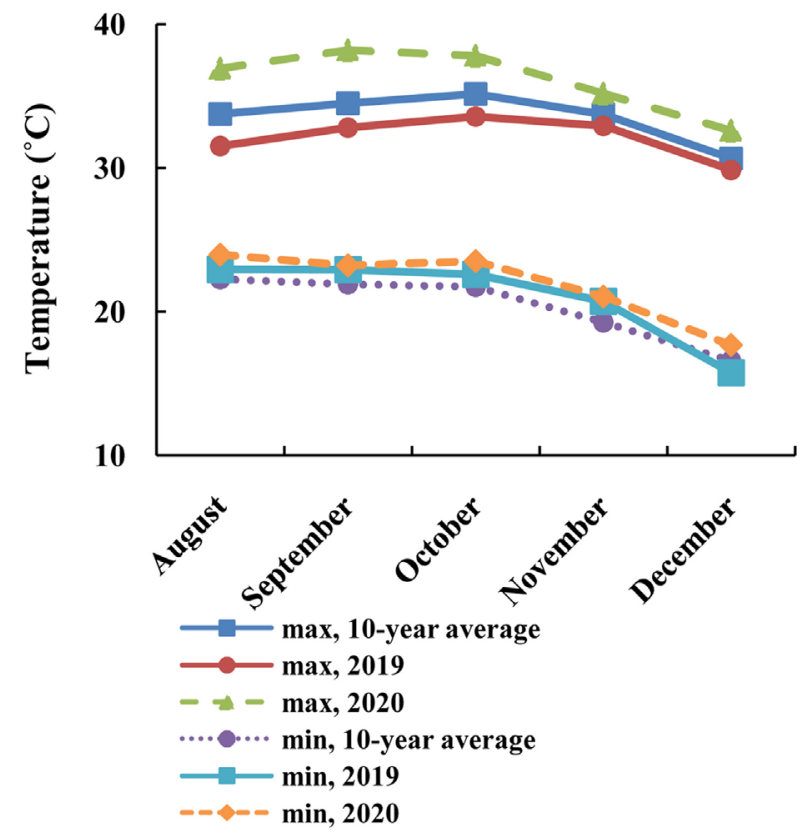

(c)

\section{Kokkokhahla}

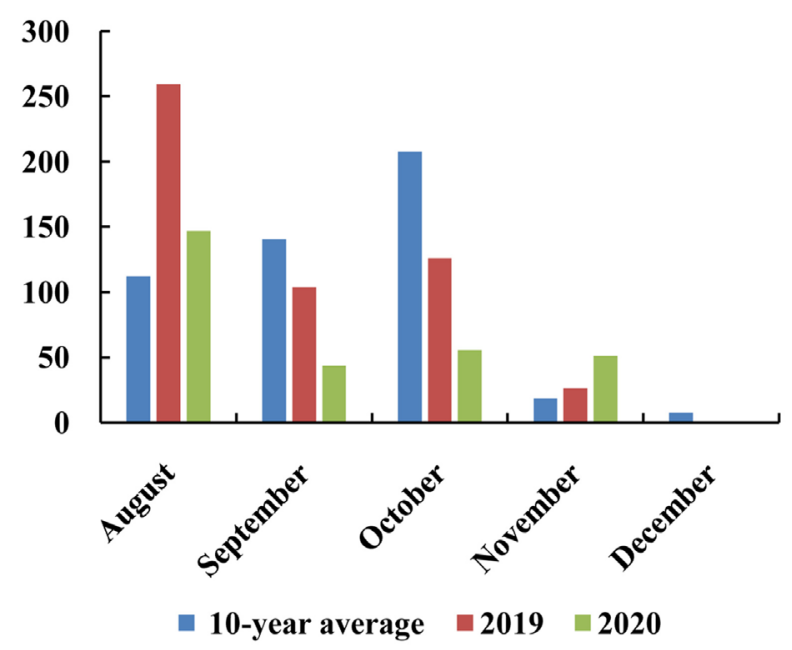

(b)

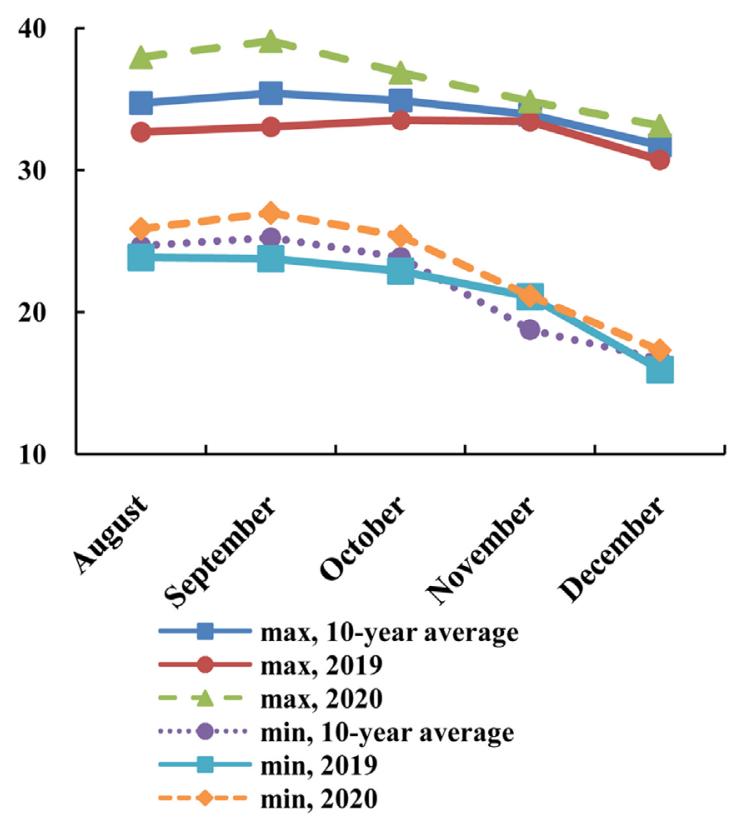

(d)

Figure 1. Weather data for 10-year average, 2019 and 2020: (a) rainfalls (c) temperature of Pawaingyoe; and (b) rainfall (d) temperature of Kokkokhahla. 


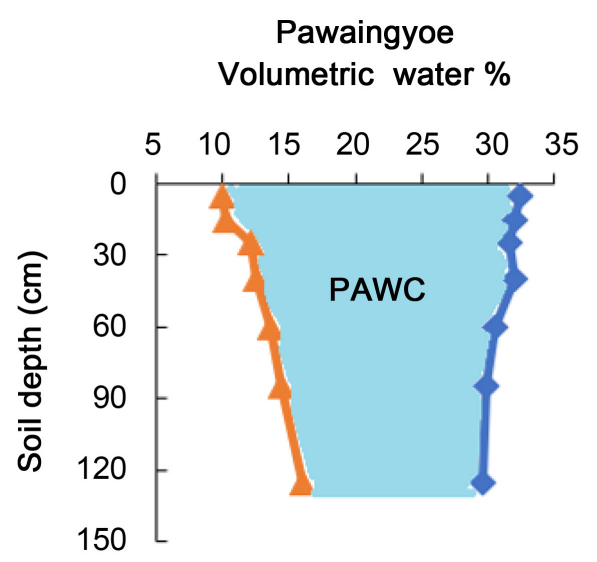

(a)

Volumetric water \%

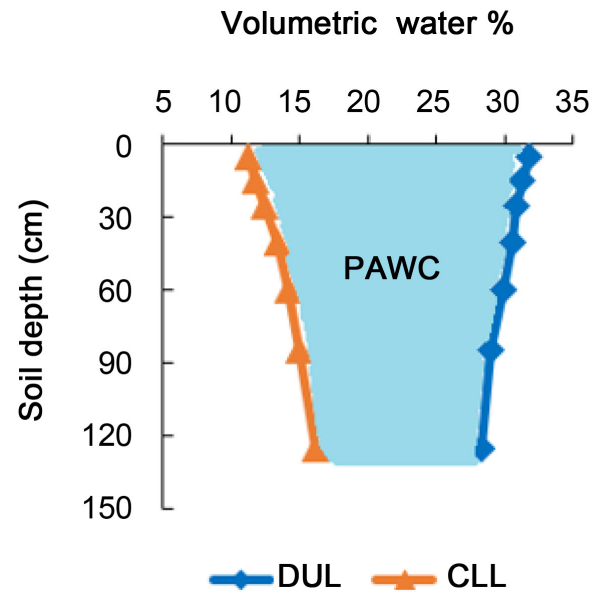

(c)
Kokkokhahla

Volumetric water \%

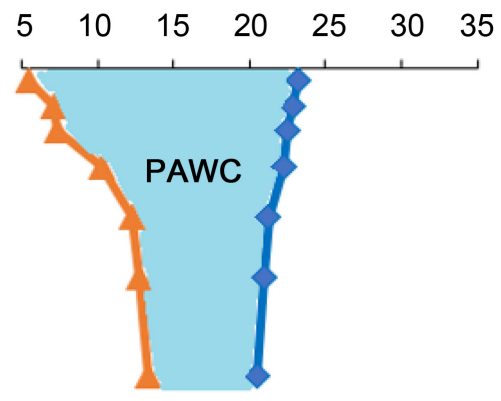

(b)
Figure 2. DUL, CLL, and PAWC of Pawaingyoe (a) 2019, (c) 2020 and; DUL, CLL, and PAWC of Kokkokhahla (b) 2019, (d) 2020.

and $150.84 \mathrm{~mm}$ in Kokkokhahla. In 2020, total PAWC (up to depth of $150 \mathrm{~cm}$ ) of these soils were $227.00 \mathrm{~mm}$ in Pawaingyoe and $132.86 \mathrm{~mm}$ in Kokkokhahla. Each year in both sites, the highest amount of available water capacity was observed in the upper soil layers $0-50 \mathrm{~cm}$ compared to deeper soil layers $50-150$ $\mathrm{cm}$ of soil profile.

The differences in soil water content within the soil profile of Pawaingyoe and Kokkokhahla were caused mainly due to difference in soil texture (Table 2). Owing to the association between clay content and soil porosity, soils with higher clay content have greater soil water storage capacity than sandy soils. Soil texture affects the water content and drainage ability of soils [18]. Another reason may be due to the effect of organic matter content. Since, Kokkokhahla soil had lower OC\% than Pawaingyoe. PAWC is positively related to soil organic matter. Soil organic matter enhances soil water retention because of its hydrophilic nature and its positive influence on soil aggregate formation [19]. It has been recognized that decreases in soil OC could reduce PAWC and soil fertility [20]. In comparing BD of each site, Pawaingyoe (clay loam) had lower amount 
of BD than Kokkokhahla (sandy loam) in all soil depth (Figure 3) and BD increased with soil depth in both sites.

\subsection{Yield and Yield Components}

Each year, there were significant differences in seed cotton yield and all yield components among the treatments in both sites (Table 3). The seed cotton yields and yield components from the plots applied with $\mathrm{N}$ fertilizer were significantly higher than that of plot without $\mathrm{N}$ fertilizer in both sites in both years. In Pawaingyoe, the seed cotton yield varied from 1386 to $2364 \mathrm{~kg} \mathrm{ha}^{-1}$ in 2019 and from 1027 to $1607 \mathrm{~kg} \mathrm{ha}^{-1}$ in 2020. The maximum values of seed cotton yield and all of yield components in Pawaingyoe was obtained from $60 \mathrm{~kg} \mathrm{~N} \mathrm{ha}^{-1}$ (T2) in 2019 and $90 \mathrm{~kg} \mathrm{~N} \mathrm{ha}^{-1}$ (T3) in 2020. In 2020 at Pawaingyoe, the maximum yield and all of the yield components were produced by $\mathrm{T} 3$ which was not significantly different from other $\mathrm{N}$ treatments, $\mathrm{T} 2$ through $\mathrm{T} 6$. According to this result, there was distinct response to $\mathrm{N}$ at $\mathrm{T} 2$ in Pawaingyoe during both experimental years. It may be assumed that further additional $\mathrm{N}$ rates were not necessary to increase seed cotton yield. These results are supported by [21] who reported that $\mathrm{N}$ influenced seed cotton yield and decrease in seed cotton yield was recorded when $\mathrm{N}$ was applied above the optimum level.

In Kokkokhahla, the seed cotton yield varied from 1088 to $1976 \mathrm{~kg} \mathrm{ha}^{-1}$ in 2019 and from 648 to $970 \mathrm{~kg} \mathrm{ha}^{-1}$ in 2020 . The maximum yield and all of the yield components in Kokkokhahla were obtained from $120 \mathrm{~kg} \mathrm{~N} \mathrm{ha}^{-1}$ (T4) and $90 \mathrm{~kg} \mathrm{~N} \mathrm{ha}^{-1}$ (T3), in 2019 and 2020, respectively. In both years, all the treatments in Pawaingyoe produced higher seed cotton yield and yield components than Kokkokhahla. The seed cotton yield and all the yield components parameters in both sites during 2020 were lower than that of 2019, particularly maximum yield of Kokkokhahla decreased 50.9\% yield of 2020 than 2019, while Pawaingyoe decreased only $32 \%$ yield of 2020 than that of 2019. This may be due to the poor performance of the cotton under low PAWC resulting from unfavorable rainfall condition. Soils with higher PAWC are more resistant on low rainfall than soils with lower PAWC.

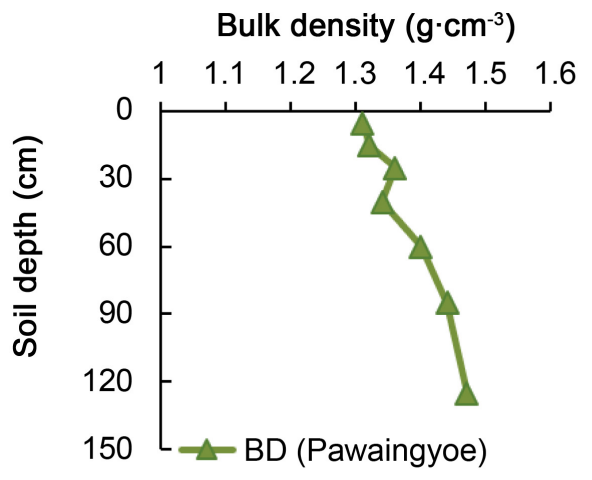

(a)
Bulk density $\left(\mathrm{g} \cdot \mathrm{cm}^{-3}\right)$

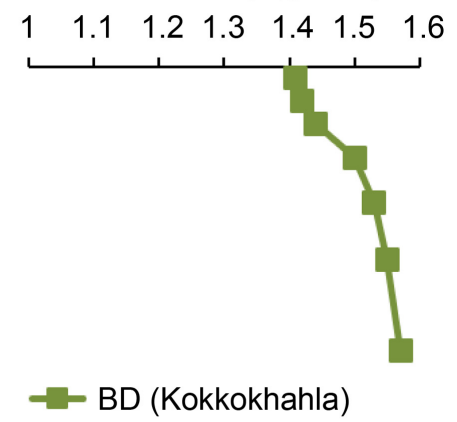

(b)

Figure 3. Bulk density of (a) Pawaingyoe and (b) Kokkokhahla. 
Table 3. Mean comparison of yield and yield components of cotton as affected by $\mathrm{N}$ fertilization in Pawaingyoe (P) and Kokkokhahla (K), in 2019 and 2010.

\begin{tabular}{|c|c|c|c|c|c|c|c|c|c|c|}
\hline \multirow[t]{2}{*}{ Treatments } & \multicolumn{2}{|c|}{ No. of bolls plant ${ }^{-1}$} & \multicolumn{2}{|c|}{$\begin{array}{l}\text { Individualboll } \\
\text { weight (g) }\end{array}$} & \multicolumn{2}{|c|}{$\begin{array}{l}1000 \text { Seed } \\
\text { weight }(\mathrm{g})\end{array}$} & \multicolumn{2}{|c|}{$\begin{array}{c}\text { Boll weight } \\
\text { plant }^{-1}\left(\mathrm{~g} \mathrm{plant}^{-1}\right)\end{array}$} & \multicolumn{2}{|c|}{ Yield $\left(\mathrm{kg} \mathrm{ha}^{-1}\right)$} \\
\hline & $\mathrm{P}$ & K & $\mathrm{P}$ & K & $\mathrm{P}$ & K & $\mathrm{P}$ & K & $\mathrm{P}$ & $\mathrm{K}$ \\
\hline \multicolumn{11}{|l|}{2019} \\
\hline $\mathrm{T} 1$ & $15.69 \mathrm{c}$ & $12.34 \mathrm{c}$ & $3.98 \mathrm{~b}$ & $3.80 \mathrm{c}$ & $96.75 \mathrm{c}$ & $98.50 \mathrm{c}$ & $48.67 \mathrm{c}$ & $39.87 \mathrm{c}$ & $1386 \mathrm{c}$ & $1088 \mathrm{c}$ \\
\hline $\mathrm{T} 2$ & $25.02 \mathrm{a}$ & $16.85 b$ & $4.84 \mathrm{a}$ & $4.03 \mathrm{bc}$ & $114.75 \mathrm{a}$ & $102.00 \mathrm{bc}$ & $83.56 a$ & $50.78 \mathrm{bc}$ & $2364 a$ & $1529 b$ \\
\hline $\mathrm{T} 3$ & $22.61 \mathrm{ab}$ & $19.08 \mathrm{ab}$ & $4.22 \mathrm{~b}$ & $4.20 \mathrm{abc}$ & $110.00 \mathrm{ab}$ & $103.00 \mathrm{abc}$ & $74.67 \mathrm{ab}$ & $61.96 \mathrm{ab}$ & $2128 \mathrm{ab}$ & $1787 \mathrm{ab}$ \\
\hline $\mathrm{T} 4$ & $20.92 \mathrm{ab}$ & $21.16 \mathrm{a}$ & $4.42 \mathrm{ab}$ & $4.53 \mathrm{a}$ & $102.50 \mathrm{bc}$ & $107.50 \mathrm{ab}$ & $73.23 \mathrm{ab}$ & $71.47 \mathrm{a}$ & $2025 \mathrm{ab}$ & $1976 a$ \\
\hline T5 & $21.92 \mathrm{ab}$ & $19.52 \mathrm{ab}$ & $4.40 \mathrm{ab}$ & $4.08 \mathrm{bc}$ & $103.50 \mathrm{abc}$ & $110.00 \mathrm{a}$ & $72.71 \mathrm{ab}$ & $66.03 a$ & $2011 \mathrm{ab}$ & $1819 \mathrm{ab}$ \\
\hline T6 & $19.01 \mathrm{bc}$ & 19.17ab & $4.17 \mathrm{~b}$ & $4.38 \mathrm{ab}$ & $102.00 \mathrm{bc}$ & $103.50 \mathrm{abc}$ & $63.72 \mathrm{bc}$ & $64.48 \mathrm{ab}$ & $1772 \mathrm{bc}$ & $1795 \mathrm{ab}$ \\
\hline $\mathrm{LSD}_{0.05}$ & 4.30 & 2.99 & 0.50 & 0.41 & 11.33 & 7.01 & 17.97 & 13.95 & 516.30 & 382.27 \\
\hline $\operatorname{Pr}>F$ & $* *$ & $* *$ & * & * & * & * & * & $* *$ & * & $* *$ \\
\hline CV\% & 13.68 & 11.04 & 7.71 & 6.47 & 7.17 & 4.47 & 17.17 & 15.67 & 17.59 & 15.23 \\
\hline \multicolumn{11}{|l|}{2020} \\
\hline $\mathrm{T} 1$ & $10.37 \mathrm{~b}$ & $7.04 \mathrm{~b}$ & $3.94 \mathrm{~b}$ & $3.87 \mathrm{~b}$ & 103.25 & 103.50 & $36.17 \mathrm{~b}$ & $25.39 \mathrm{~b}$ & $1027 \mathrm{~b}$ & $648 \mathrm{~b}$ \\
\hline $\mathrm{T} 2$ & $16.76 \mathrm{a}$ & $8.25 b$ & $4.63 \mathrm{a}$ & $4.23 \mathrm{ab}$ & 110.00 & 103.00 & $56.07 \mathrm{a}$ & $28.46 \mathrm{~b}$ & $1553 a$ & $805 \mathrm{ab}$ \\
\hline $\mathrm{T} 3$ & $17.22 \mathrm{a}$ & $11.53 a$ & $4.73 a$ & $4.74 \mathrm{a}$ & 111.00 & 106.50 & $59.45 a$ & $40.11 \mathrm{a}$ & $1607 a$ & $970 \mathrm{a}$ \\
\hline $\mathrm{T} 4$ & $16.41 \mathrm{a}$ & $11.30 \mathrm{a}$ & $4.59 \mathrm{a}$ & $4.77 \mathrm{a}$ & 112.25 & 109.50 & $55.86 \mathrm{a}$ & $39.48 a$ & $1515 a$ & $958 \mathrm{a}$ \\
\hline T5 & $15.49 \mathrm{a}$ & $11.13 \mathrm{a}$ & $4.40 \mathrm{a}$ & $4.53 \mathrm{a}$ & 110.50 & 106.50 & $54.35 \mathrm{a}$ & $40.00 \mathrm{a}$ & $1471 \mathrm{a}$ & $940 \mathrm{a}$ \\
\hline T6 & $14.87 \mathrm{a}$ & $11.08 \mathrm{a}$ & $4.34 \mathrm{ab}$ & $4.48 \mathrm{a}$ & 104.50 & 108.00 & $51.66 \mathrm{a}$ & $38.39 \mathrm{a}$ & $1393 a$ & $936 a$ \\
\hline $\mathrm{LSD}_{0.05}$ & 3.79 & 2.28 & 0.45 & 0.58 & 6.72 & 9.34 & 17.81 & 7.38 & 361.68 & 189.75 \\
\hline $\operatorname{Pr}>F$ & * & $* *$ & * & * & ns & ns & * & $* *$ & * & * \\
\hline CV\% & 16.55 & 14.94 & 6.73 & 8.60 & 4.10 & 5.84 & 14.03 & 13.87 & 16.81 & 14.37 \\
\hline
\end{tabular}

Means followed by the same letter in each column are not significantly different at $5 \% \mathrm{LSD}$; ${ }^{*}=$ significant at $1 \%$ level; ${ }^{*}=$ significant at $5 \%$ level; $\mathrm{ns}=$ non-significant.

\subsection{Agronomic Nitrogen Use Efficiency (NUE)}

Agronomic NUE evaluates $\mathrm{N}$ fertilizer investment benefit and it is linearly related to specific seed cotton yield and $\mathrm{N}$ fertilizer prices. Understanding how NUE changes with $\mathrm{N}$ fertilization rates will assist producers in $\mathrm{N}$ management decisions that affect both the profitability and $\mathrm{N}$ impact on the environment [22]. Each year in both sites, NUE was significantly affected by $\mathrm{N}$ application and NUE gradually decreased with increasing $\mathrm{N}$ rate, more than $60 \mathrm{~kg} \mathrm{~N} \mathrm{ha}^{-1}$ at Pawaingyoe and more than $90 \mathrm{~kg} \mathrm{~N} \mathrm{ha}^{-1}$ at Kokkokhahla (Figure 4). According to Fan [23], who reported the low nutrient use efficiency may be attributed to fertilizer overuse and high nutrient loss. Owing to the law of diminishing returns, the yield per unit $\mathrm{N}$ supply declines with increasing $\mathrm{N}$ supply [24]. The highest values of NUE in Pawaingyoe were obtained from $60 \mathrm{~kg} \mathrm{~N}^{-1}$ (T2) with the value 16.31 in 2019 and 8.77 in 2020. In Kokkokhahla, the highest values of NUE was obtained from $90 \mathrm{~kg} \mathrm{~N} \mathrm{ha}^{-1}$ (T3) with the value 7.76 in 2019 and 3.58 in 2020. In both years, NUE values of all treatments were lower in Kokkokhahla 


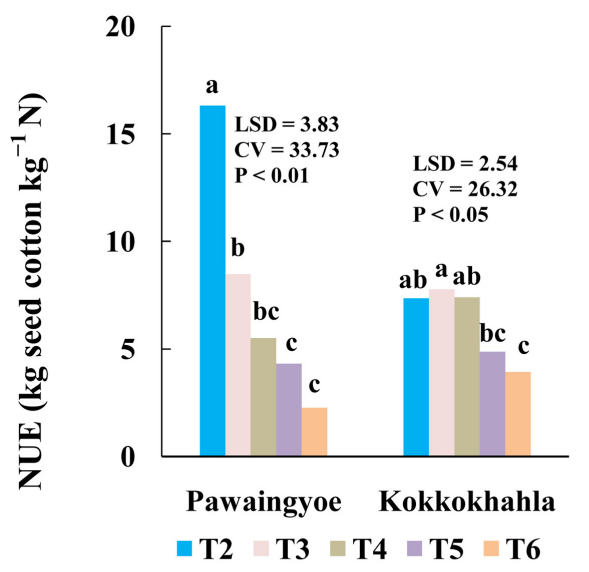

(a)

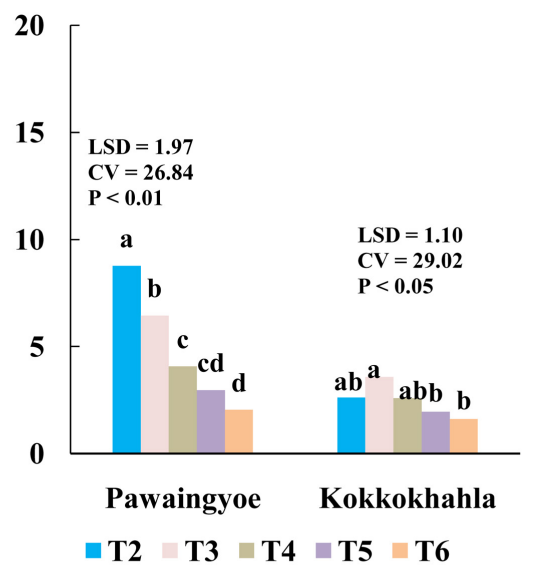

(b)

$$
\left(\mathrm{T} 2=60, \mathrm{~T} 3=90, \mathrm{~T} 4=120, \mathrm{~T} 5=150 \text { and } \mathrm{T} 6=180 \mathrm{~kg} \mathrm{~N} \mathrm{ha}^{-1}\right)
$$

Figure 4. Effect of $\mathrm{N}$ fertilization rates on NUE in Pawaingyoe and Kokkokhahla, (a) 2019 and (b) 2020.

than Pawaingyoe. Fertilizer use efficiency in the coarse-textured permeable soils is very low due to excessive $\mathrm{N}$ losses [25]. The decrease in NUE at higher $\mathrm{N}$ rates was because the increase in yield was lower than the increase in $\mathrm{N}$ rate. This is probably because yield increase with $\mathrm{N}$ is not linear and at higher $\mathrm{N}$ rate there was no yield increase. NUE of both sites in 2020 were lower than that of 2019, particularly in Kokkokhahla. The reason might be due to low rainfall in 2020 than 2019 this led to low soil water content, and consequently low $\mathrm{N}$ availability (Figure 1).

\subsection{Fiber Quality}

In 2019, there was a significant $\mathrm{N}$ application effect for fiber strength at Pawaingyoe, while there was a significant $\mathrm{N}$ application effect for both fiber length and strength at Kokkokhahla (Table 4). At Pawaingyoe, T2 gave maximum fiber strength $\left(8.23 \mathrm{lb} \mathrm{mg}^{-1}\right)$, while at Kokkokhahla $\mathrm{T} 4$ gave greater fiber length $(28.32 \mathrm{~mm})$, fiber strength $\left(8.23 \mathrm{lb} \mathrm{mg}^{-1}\right)$ than other treatments. However, non-significant $\mathrm{N}$ application effect for all fiber qualities in 2020 at both sites. The reason might be low rainfall in 2020 leading to poor soil moisture. Consequently, fiber quality parameters were not affected by $\mathrm{N}$ application in 2020. Fiber properties of cotton may be affected by other factors such as, temperature, humidity, soil moisture [26] and fertilizers [27].

\subsection{Discussion}

This study highlighted that PAWC and the variability of seasonal rainfall may be a major source of variation on the response of cotton by $\mathrm{N}$ application in respective site. In both years, the growth and yield of cotton were higher in Pawaingyoe, because of high PAWC in Pawaingyoe and thus greater level of water availability during cotton development. The results are consistent with findings of [28] who reported that soils with high PAWC provided a larger buffer to store water from 
Table 4. Effect of nitrogen fertilization on fiber quality of cotton in Pawaingyoe (P) and Kokkokhahla (K), in 2019 and 2010.

\begin{tabular}{|c|c|c|c|c|c|c|c|c|c|c|}
\hline \multirow[t]{2}{*}{ Treatments } & \multicolumn{2}{|c|}{$\begin{array}{l}\text { Fiber length } \\
\quad(\mathrm{mm})\end{array}$} & \multicolumn{2}{|c|}{$\begin{array}{l}\text { Fiber strength } \\
\quad\left(\mathrm{lb} \mathrm{mg}^{-1}\right)\end{array}$} & \multicolumn{2}{|c|}{$\begin{array}{c}\text { Fiber fineness } \\
\text { (micronaire) }\end{array}$} & \multicolumn{2}{|c|}{ Maturity ratio } & \multicolumn{2}{|c|}{$\begin{array}{c}\text { Ginning out turn } \\
(\%)\end{array}$} \\
\hline & $\mathrm{P}$ & K & $\mathrm{P}$ & K & $\mathrm{P}$ & $\mathrm{K}$ & $\mathrm{P}$ & $\mathrm{K}$ & $\mathrm{P}$ & K \\
\hline \multicolumn{11}{|l|}{2019} \\
\hline $\mathrm{T} 1$ & 26.37 & $26.38 \mathrm{c}$ & $7.85 c$ & $7.82 \mathrm{~d}$ & 5.30 & 5.00 & 0.93 & 0.95 & 32.38 & 32.72 \\
\hline $\mathrm{T} 2$ & 27.94 & $26.40 c$ & $8.23 a$ & $7.97 \mathrm{~cd}$ & 4.78 & 5.15 & 0.98 & 0.95 & 34.23 & 32.18 \\
\hline $\mathrm{T} 3$ & 27.43 & $27.91 \mathrm{ab}$ & $8.11 \mathrm{ab}$ & $8.04 \mathrm{bc}$ & 4.80 & 4.90 & 0.95 & 0.97 & 33.17 & 32.77 \\
\hline $\mathrm{T} 4$ & 27.15 & $28.32 \mathrm{a}$ & $7.94 b c$ & $8.23 \mathrm{a}$ & 4.80 & 4.80 & 0.93 & 0.98 & 33.62 & 33.79 \\
\hline T5 & 27.61 & $26.89 b c$ & $7.98 b c$ & $8.15 \mathrm{ab}$ & 4.98 & 4.83 & 0.95 & 0.95 & 33.63 & 33.44 \\
\hline T6 & 26.69 & $26.63 c$ & $7.91 b c$ & $8.11 \mathrm{abc}$ & 5.28 & 5.10 & 0.95 & 0.93 & 33.19 & 33.43 \\
\hline $\mathrm{LSD}_{0.05}$ & 1.95 & 1.12 & 0.21 & 0.18 & 0.75 & 0.49 & 0.08 & 0.09 & 2.15 & 1.62 \\
\hline $\operatorname{Pr}>F$ & ns & $* *$ & * & $* *$ & ns & ns & ns & ns & ns & ns \\
\hline CV\% & 4.75 & 2.73 & 1.73 & 1.47 & 9.96 & 6.67 & 5.54 & 6.13 & 4.26 & 3.26 \\
\hline \multicolumn{11}{|l|}{2020} \\
\hline $\mathrm{T} 1$ & 25.41 & 25.34 & 7.92 & 7.88 & 5.43 & 5.50 & 0.93 & 0.93 & 33.41 & 32.94 \\
\hline $\mathrm{T} 2$ & 26.55 & 25.99 & 8.23 & 8.11 & 5.28 & 5.30 & 0.95 & 0.93 & 34.08 & 33.97 \\
\hline $\mathrm{T} 3$ & 26.67 & 26.97 & 7.93 & 8.08 & 5.58 & 4.93 & 0.93 & 0.95 & 33.93 & 34.11 \\
\hline $\mathrm{T} 4$ & 26.67 & 27.44 & 7.93 & 7.97 & 5.55 & 5.05 & 0.98 & 0.95 & 33.54 & 34.94 \\
\hline T5 & 26.36 & 26.14 & 8.23 & 8.05 & 5.43 & 5.10 & 0.93 & 0.98 & 34.38 & 35.00 \\
\hline T6 & 26.37 & 26.19 & 8.20 & 8.06 & 5.35 & 5.23 & 0.95 & 0.95 & 34.25 & 34.04 \\
\hline $\mathrm{LSD}_{0.05}$ & 1.06 & 1.79 & 0.35 & 0.21 & 0.37 & 0.55 & 0.08 & 0.09 & 1.54 & 2.05 \\
\hline $\operatorname{Pr}>F$ & ns & ns & ns & ns & ns & ns & ns & ns & ns & ns \\
\hline CV\% & 2.66 & 4.50 & 2.91 & 1.76 & 4.47 & 6.98 & 5.60 & 5.98 & 3.01 & 3.98 \\
\hline
\end{tabular}

Means followed by the same letter in each column are not significantly different at $5 \% \mathrm{LSD} ;{ }^{\star *}=$ significant at $1 \%$ level; ${ }^{\star}=$ significant at $5 \%$ level; ns $=$ non-significant.

variable rainfall and to supply it to crops during dry periods and therefore were less affected by rainfall decreases compared to soils with low PAWC. Kokkokhahla (low PAWC) has sandy loam texture and cotton grown on this soil was more responsive to $\mathrm{N}$ than clay loam texture soil of Pawaingyoe (high PAWC), probably because organic $\mathrm{N}$ reserves are lower, the soil is more often dry, and nitrate $\mathrm{N}$ cannot be held in the profile against leaching. Soils with low PAWC are typically sandier and crops grown on these soils are more responsive to $\mathrm{N}$ than finer textured soils [29].

When comparing the two sites, Pawaingyoe (high PAWC) was found to be better in terms of yield components, yield and NUE than Kokkokhahla (low PAWC) in both years, as high PAWC can lead to more water use and the availability of water to crops. When comparing the two years, the more favorable growing seasons rainfall conditions in 2019 (wet year) resulted in much higher growth and yield than 2020 (dry year) in both sites and more response to $\mathrm{N}$ application was observed in wet year than dry year. 


\section{Conclusion}

Soil water content and nutrient availability are two main factors of limiting plant growth and productivity in rainfed region. Among all nutrients, $\mathrm{N}$ is the main essential element for most of the biological processes in cotton plant. For cotton production, an improved understanding of $\mathrm{N}$ application in relation with PAWC would help the grower's better management of $\mathrm{N}$ for optimal yield and fiber quality. This study evaluated the optimum nitrogen $(\mathrm{N})$ fertilizer rate for yield and quality of rainfed cotton under respective PAWC. Our results show that to achieve high yield and maximum NUE for both wet and dry years, T2 (60 $\mathrm{kg} \mathrm{N} \mathrm{ha}{ }^{-1}$ ) was the appropriate rate for Pawaingyoe (clay loam, high PAWC) for both years. The range between T3 and T4 (90 - $\left.120 \mathrm{~kg} \mathrm{~N} \mathrm{ha}^{-1}\right)$ was the suitable rate for Kokkokhahla (sandy loam, low PAWC) in 2019. However, the treatment T3 (90 kg N ha-1) was the most appropriate rate for Kokkokhahla in 2020. It is necessary to carry out further research on $\mathrm{N}$ management in different cotton cultivars under different PAWC and rainfall conditions in rainfed area.

\section{Acknowledgements}

We gratefully acknowledge to Myanmar Awba Group and ACIAR Project (LWR 2014/075) for their partial financial and technical support for conducting this research work.

\section{Conflicts of Interest}

The authors declare no conflicts of interest regarding the publication of this paper.

\section{References}

[1] Sahito, A., Baloch, Z.A., Mahar, A., Otho, S.A., Kalhoro, S.A., Ali, A., Ali, F., et al. (2015) Effect of Water Stress on the Growth and Yield of Cotton Crop (Gossypium hirsutum L.). American Journal of Plant Sciences, 6, 1027. https://doi.org/10.4236/ajps.2015.67108

[2] Win, T. (2008) Cotton Research in Myanmar-An Overview. 4th Meeting of the Asian Cotton Research and Development Network, International Cotton Advisory Committee (ICAC).

[3] Tin, P. (2003) Myanmar's Perspective on Increasing Cotton Production in Light of Global Production Changes. Institute of Developing Economics, Japan External Trade Organization. VRF Series, 369.

[4] Wang, B., Liu, D., Asseng, S., Macadam, I. and Yu, Q. (2017) Modelling Wheat Yield Change under $\mathrm{CO}_{2}$ Increase, Heat and Water Stress in Relation to Plant Available Water Capacity in Eastern Australia. European Journal of Agronomy, 90, 152-161. https://doi.org/10.1016/j.eja.2017.08.005

[5] Lal, R. (1991) Current Research on Crop Water Balance and Implications for the Future. Proceedings of the International Workshop of the Soil Water Balance in the Sudano-Sahelian Zone, Niamey, 18-23 February 1991, 31-44.

[6] Shaxson, T.F. and Barber, R.G. (2003) Optimizing Soil Moisture for Plant Production: The Significance of Soil Porosity (No. 79). UN-FAO, Rome. 
[7] Shah, S.H. (2008) Effects of Nitrogen Fertilization on Nitrate Reductase Activity, Protein, and Oil Yields of Nigella sativa L. as Affected by Foliar GA3 Application. Turkish Journal of Botany, 32, 165-170.

[8] Bondada, B.R. and Oosterhuis, D.M. (2001) Canopy Photosynthesis, Specific Leaf Weight, and Yield Components of Cotton under Varying Nitrogen Supply. Journal of Plant Nutrition, 24, 469-477. https://doi.org/10.1081/PLN-100104973

[9] Hutmacher, R.B., Travis, R.L., Rains, D.W., Vargas, R.N., Roberts, B.A., Weir, B.L., Delgado, R., et al. (2004) Response of Recent Acala Cotton Varieties to Variable Nitrogen Rates in the San Joaquin Valley of California. Agronomy Journal, 96, 48-62. https://doi.org/10.2134/agronj2004.0048

[10] Hearn, A.B. (1981) Cotton Nutrition. Field Crop Abstracts, 34, 11-34.

[11] Pan, W.L., Huggins, D.R., Malzer, G.L., Douglas Jr., C.L. and Smith, J.L. (1997) Field Heterogeneity in Soil-Plant Nitrogen Relationships: Implications for Site-Specific Management. In: The State of Site Specific Management for Agriculture, Wiley, Hoboken, 81-99. https://doi.org/10.2134/1997.stateofsitespecific.c5

[12] Dong, H., Li, W., EgrinyaEneji, A. and Zhang, D. (2012) Nitrogen Rate and Plant Density Effects on Yield and Late-Season Leaf Senescence of Cotton Raised on a Saline Field. Field Crops Research, 126, 137-144. https://doi.org/10.1016/j.fcr.2011.10.005

[13] Prasad, R. and Power, J.F. (1995) Nitrification Inhibitors for Agriculture, Health, and the Environment. Advances in Agronomy, 54, 233-281. https://doi.org/10.1016/S0065-2113(08)60901-3

[14] Singh, J. and Mannikar, N.D. (1988) Studies on Nitrogen Transformation in Vertisol as Influenced by Different N Carriers and Its Effect on Growth, Yield and Uptake in Rainfed Cotton. Classification, Management and Use Potential of Swell Shrink Soils. Oxford IBH, New Delhi, 207-210.

[15] McConnell, J.S., Baker, W.H. and Frizzell, B.S. (1996) Distribution of Residual Nitrate-Nitrogen in Long-Term Fertilization Studies of an Alfisol Cropped to Cotton. Journal of Environmental Quality, 25, 1389-1394. https://doi.org/10.2134/jeq1996.00472425002500060032x

[16] Dalgliesh, N.P. and Foale, M.A. (1998) Soil Matters: Monitoring Soil Water and Nutrients in Dryland Farming. Agricultural Production Systems Research Unit, CSIRO, Toowoomba.

[17] Novoa, R. and Loomis, R. (1981) Nitrogen and Plant Production. In: Soil Water and Nitrogen in Mediterranean- Type Environments, Springer, Berlin, 177-204. https://doi.org/10.1007/978-94-015-0861-2 7

[18] Amooh, M.K. and Bonsu, M. (2015) Effects of Soil Texture and Organic Matter on Evaporative Loss of Soil Moisture. Journal of Global Agriculture and Ecology, 3, 152-161.

[19] Lal, R., Kimble, J.M., Follett, R.F. and Stewart, B.A. (1997) Soil Processes and the Carbon Cycle (Vol. 11). CRC Press, Boca Raton, 169-197.

[20] McCarthy, J.J., Canziani, O.F., Leary, N.A., Dokken, D.J. and White, K.S. (2001) Climate Change: Impacts, Adaptation, and Vulnerability: Contribution of Working Group II to the Third Assessment Report of the Intergovernmental Panel on Climate Change (Vol. 2). Cambridge University Press, Cambridge.

[21] Bell, P.F., Boquet, D.J., Millhollon, E., Moore, S., Ebelhar, W., Mitchell, C.C., et al. (2003) Relationships between Leaf Blade Nitrogen and Relative Seed Cotton Yields. Crop Science, 43, L1367-L1374. https://doi.org/10.2135/cropsci2003.1367 
[22] Rochester, I.J. (2011) Assessing Internal Crop Nitrogen Use Efficiency in High-Yielding Irrigated Cotton. Nutrient Cycling in Agroecosystems, 90, 147-156. https://doi.org/10.1007/s10705-010-9418-9

[23] Fan, M., Shen, J., Yuan, L., Jiang, R., Chen, X., Davies, W.J. and Zhang, F. (2012) Improving Crop Productivity and Resource Use Efficiency to Ensure Food Security and Environmental Quality in China. Journal of Experimental Botany, 63, 13-24. https://doi.org/10.1093/jxb/err248

[24] Gastal, F., Lemaire, G., Durand, J.L. andLouarn, G. (2015) Quantifying Crop Responses to Nitrogen and Avenues to Improve Nitrogen-Use Efficiency. In: Crop Physiology: Applications for Genetic Improvement and Agronomy, Academic Press, San Diego, 161-206. https://doi.org/10.1016/B978-0-12-417104-6.00008-X

[25] Tilman, D., Cassman, K.G., Matson, P.A., Naylor, R. and Polasky, S. (2002) Agricultural Sustainability and Intensive Production Practices. Nature, 418, 671-677. https://doi.org/10.1038/nature01014

[26] Killi, F.A., Efe, L.A. and Mustafayev, S.E. (2005) Genetic and Environmental Variability in Yield, Yield Components and Lint Quality Traits of Cotton. International Journal of Agriculture and Biology, 7, 1007-1010.

[27] Abid, M., Ahmad, N., Ali, A., Chaudhry, M.A. and Hussain, J. (2007) Influence of Soil-Applied Boron on Yield, Fiber Quality and Leaf Boron Contents of Cotton (Gossypium hirsutum L.). Journal of Agriculture and Social Sciences, 3, 7-10.

[28] Wang, E., Cresswell, H., Xu, J. and Jiang, Q. (2009) Capacity of Soils to Buffer Impact of Climate Variability and Value of Seasonal Forecasts. Agricultural and Forest Meteorology, 149, 38-50. https://doi.org/10.1016/j.agrformet.2008.07.001

[29] Oliver, Y.M. and Robertson, M.J. (2009) Quantifying the Benefits of Accounting for Yield Potential in Spatially and Seasonally Responsive Nutrient Management in a Mediterranean Climate. Soil Research, 47, 114-126.

https://doi.org/10.1071/SR08099 